\title{
AT A COUNTRY FAIR
}

AT a bygone Western country fair

I saw a giant led by a dwarf

With a red string like a long thin scarf;

How much he was the stronger there

The giant seemed unaware.

And then I saw that the giant was blind, And the dwarf a shrewd-eyed little thing; The giant, mild, timid, obeyed the string

As if he had no independent mind,

Or will of any kind.

Wherever the dwarf decided to go

At his heels the other trotted meekly,

(Perhaps - I know not - reproaching weakly)

Like one Fate bade that it must be so,

Whether he wished or no.

Various sights in various climes

I have seen, and more I may see yet,

But that sight never shall I forget,

And have thought it the sorriest of pantomimes,

If once, a hundred times! 